\title{
Transnational Memories
}

\author{
ALEIDA ASSMAN N \\ Universität Konstanz, 78457, Konstanz, Germany. E-mail: Aleida.Assmann@, \\ uni-konstanz.de
}

\begin{abstract}
The 'transnational turn', which is challenging bounded views on national belonging, also opens up promising perspectives for memory studies. It fosters a rethinking and reconfiguring of national memories in the context of transnational connectedness. My sketch of seven types of transnational memories points to different empirical contexts in which states, politicians, jurists, activists, artists and scholars go beyond national borders and interests to conceptualise new forms of belonging, solidarity and cultural identification in a world characterised by streams of migration and the lingering impact of traumatic and entangled pasts.
\end{abstract}

\section{Introduction}

Over the last five years, we have been able to witness the remarkable career of the term 'transnational', which is in the process of replacing previous terms such as 'post-colonial' or 'multi-cultural'. While these latter terms have, in the meantime, lost much of their glamour, the new term seems to encapsulate a vision of a better world to which cultural studies can help contribute with its new terminology. Hence, a 'transnational turn' has been announced by historians and theorists in various subfields of cultural studies, such as literary studies, media studies, migration studies or memory studies. Looking beyond the border of nations is certainly not a totally new enterprise; more inclusive perspectives and comparative methodologies had for a long time been implemented in imperial, international and global history.

The new focus on the transnational, however, is more specific. It

examines units that spill over and seep through national borders, units both greater and smaller than the nation-state. [...] Transnational history does not simply cover more ground; it is not equivalent to world history. [...] Perhaps the core of transnational history is the challenge it poses to the hermeneutic preeminence of nations. Without losing sight of the 'potent forces' nations have become, it understands them as 'fragile, constructed, imagined'. Transnational history treats the nation as one among a range of social phenomena to be studied, rather than the frame of the study itself. ${ }^{1}$

When analysing the term 'transnational' more closely, we soon detect that it is deployed not only as a descriptive tool but also as a prescriptive term that carries 
normative implications. Its success clearly relies heavily on this inherent value dimension that endows it with a new perspective and vision. This normative stance is often underpinned by a cosmopolitan ethos that betrays a general dissatisfaction with the dated nineteenth-century ideal of the autonomous, free, coherent and bounded nation and the desire to move forward towards a new national imaginary stimulated by ongoing local and global reconfigurations. The general challenge of the 'trans' is to go beyond national identification, investments and interests and explore new forms of belonging and cultural identification in a world characterised by streams of migration and dispersed and displaced populations with different historical trajectories. In this context, the transnational can also "call forth different representations of the past. It does not negate the past, but it does foster a rethinking of the national in the light of newly invented spatial and temporal coordinates'. 'Trans' stands of course for 'transit', emphasising movement in space across national borders, but it also stands for 'translations', the cultural work of reconfiguring established national themes, references, representations, images and concepts. Nations are not elided in this transnational perspective, but they are symbolically and politically recast. They are imagined differently as inherently and externally relational, embedded and contextualised, always implicated in and partaking of larger processes and changes.

The interpretive framework of the transnational turn also carries a promising potential for memory studies as it stimulates new perspectives on the larger political and cultural contexts in which memories are selected, constructed and contested. Given the often celebratory and somewhat hyperbolic rhetoric of the 'trans', I will follow a different route here and reflect more empirically on specific contexts to which the term has been or can be applied.

\section{Globalised Memories: Diffusions and Repercussions in a Global Arena}

Taking memory studies from the level of the nation to the global arena was the aim of a book I coedited with Sebastian Conrad, a historian of globalisation at the Free University Berlin. In the introduction to the publication we wrote:

Until recently, the dynamics of memory production unfolded primarily within the bounds of the nation-state; coming to terms with the past was largely a national project. Under the impact of global mobility and movements, this has changed fundamentally. Global conditions have powerfully impacted on memory debates, and, at the same time, memory has entered the global stage and global discourse. Today, memory and the global have to be studied together, as it has become impossible to understand the trajectories of memory outside a global frame of reference. ${ }^{3}$

Memories, it was agreed, were increasingly leaking or breaking out of the 'container of the nation-state ${ }^{4}$ due to the formation of a global arena that rests mainly on two pillars:

- the connectivity of digital technologies and media, and

- new transnational actors and networks that are reshaping the global world from above and below. 
In an article with the programmatic title 'Travelling Memory' (2012), Astrid Erll has argued against what has come to be termed 'methodological nationalism' in the study of cultural memory, looking at forms in which memories are generated and circulated outside the national frame. Her concept of 'traveling memory' is geared to a world of communication flows and great migrant mobility. As media and people are incessantly on the move, she argues that new possibilities arise 'for shaping post-national citizenship and for creating new lines of solidarity within the global arena'. In their influential book on The Holocaust in the Global Age ${ }^{4}$ Daniel Levy and Natan Sznaider had already argued along similar lines, describing a global scenario, in which the constraints of ethnic nationalism and particularism give way to a universal and cosmopolitan memory for post-national citizens of the world. In these studies, the agents of this new change are new communication technologies. Change is attributed to technological structures evolving according to the self-propelling progress of modernisation that is going global. Within this rather abstract conceptual framework, there is little place for human agency. Moving directly from nationalism to the global sphere of media circulation is, therefore, a problematic step that covers up many problems that are challenging and vexing memory studies at this present stage. Memory is taken all too easily beyond all boundaries if we focus directly on a cosmopolitan community that is composed of none other than humanity itself.

While this is a beautiful idea, we also need to acknowledge that some borders continue to exist and are even re-erected by new memory-communities. One way to adopt a more realistic perspective is to follow Ann Rigney's observation that there is a 'striking lack of attention to Europe' in most of these studies. Her point is that Europe stands for a different form of the transnational that 'represents neither the national nor the global' which makes this case 'theoretically so fascinating'.

Coming back to the idea that it is not only the connectivity of digital technologies and media itself, but also the work of new transnational actors and institutional networks that are reshaping the global world from above and below, this contribution will focus more directly on specific cases, projects and political contexts in which transnational memories are being formed.

\section{The Holocaust as a Transnational Memory}

On 27 January 2000, Swedish Prime Minister Göran Persson invited representatives of 16 nations (among them 13 present and future members of the European Union) to a forum in Stockholm to discuss and define a common framework for commemorating and teaching the Holocaust. The result was 'The International Task Force on Holocaust Education, Remembrance and Research' (ITF). ${ }^{6}$ In the first year of the new millennium and 55 years after the liberation of Auschwitz, there was general agreement that the murder of six million European Jews should become a common memory and, in turn, that this memory should inform the values of European civil society and protect the rights of minorities. The last article of the Stockholm declaration adopts a universalist perspective as it states:

It is appropriate that this, the first major international conference of the new millennium, declares its commitment to plant the seeds of a better future amidst the 
soil of a bitter past. We empathize with the victims' suffering and draw inspiration from their struggle. Our commitment must be to remember the victims who perished, respect the survivors still with us, and reaffirm humanity's common aspiration for mutual understanding and justice.

The ITF had two aims:

(1) to carry the memory of the Holocaust across the threshold of the new millennium to transform it into a long-term cultural memory at the moment when the communicative memory of survivor-witnesses was fading away, and

(2) to carry the memory of the Holocaust across European borders by creating a transnational memory community with an extended infrastructure of social institutions, finance and cooperative networks.

To further coordinate these activities, the ITF asked the countries to introduce a common Holocaust memorial day. In 1999 Stuart Eizenstat, another expert of the ITF, commented on the extraordinary character of the event: 'for the first time, heads of government agreed to cooperate directly with other countries, through diplomatic and other channels, to strengthen Holocaust education efforts on both sides of the Atlantic and beyond'?

What had started in Stockholm and Washington was brought back to Europe. On 27 January 2005, the European Parliament in Brussels declared the Day of the Liberation of Auschwitz as a European day of commemoration and passed a resolution against anti-Semitism in Europe. With this declaration, participation in the Holocaust community of memory became part of the entry ticket into the EU. Today, the task force comprises 31 states. Although most of its member states are located within the geographic area of Europe, it also transcends Europe, as it includes the states of Israel, the United States and Argentina. It became even more trans-European when, in January 2005, Kofi Annan celebrated for the first time a Holocaust Remembrance Day in the United Nations.

According to the statutes of the ITF, membership in this transnational memory community is open to all countries of the United Nations. While the priority of Holocaust memory is written into its statutes, the ITF/IHRA has also expanded its thematic focus since 2007 to include other genocides, such as that of the Armenians and of the Sinti and Roma. In this case, we can speak of a hegemonic transnational memory that is supported by an extensive network of states. The term NGO is slightly misleading as the members of this network comprise the states and their official representatives.

\section{A Shared Memory for a Transnational Collective (The EU Museum)}

In his introduction to a book published in 2001, historian Christian Meier wrote:

Can we still, in our time, find access to history? The best evidence that this seems to be no longer possible is the fact that the political formation of the European Union, in spite of its multiple activities, has not yet given a thought to how to remember its 
past - something that used to be self-evident for all nations. The only thing to be heard about history today is the 'never again' relating to War, Auschwitz and possibly, if the extension of the EU towards the east progresses further, also to the GULAG. ${ }^{8}$

What Meier considered to be impossible at the beginning of the millennium - a historical memory and shared knowledge of the past that goes beyond the common memory of the Holocaust - has been given much reflection since the 1990s and is still in the making. This process of a historical transnational memory of the EU, however, proved to be more difficult to construct than its commissioners and makers had anticipated. This memory, indeed, is still in the making. The task is exceptionally difficult, however, as in this case, we are talking not of one memory shared ideally by all member states, but of Europe's multifarious cultural traditions and histories that have to be 'translated', transformed or boiled down into a shared legacy. The institutional focus for shaping this transnational memory is a 'Museum of Europe' in Brussels, the opening of which had been repeatedly announced - and postponed. It was established in the mid-1990s and renamed as the 'European House of History' in 2008. This emerging European memory is historically a new challenge; it has the purpose of backing up a supra-national identity by creating a common focus within the manifest disparity of the different experiences and orientations of the various member states. As this project turned out to be far too complex and controversial with little prospect of arriving at a solution that will eventually satisfy all memberstates, the project itself had to be radically revised. The task of the new museum has now shifted from a site of European history to a site where process and 'work of European unification is jointly cultivated' to help the members generate a 'shared view on the past, present and future of Europe'.

\section{Multidirectional Memories: One Memory as a Prism for Another}

More than four decades ago, Michel Foucault reflected on the open structure of texts. What he wrote about the book can also easily be applied to memory and, as I want to show, to national memory:

The frontiers of a book are never clear-cut: beyond the title, the first lines, and the last full stop, beyond its internal configuration and its autonomous form, it is caught up in a system of references to other books, other texts, other sentences: it is a node within a network. ${ }^{10}$

In this passage, Foucault has anticipated ideas that have become the basics for new digital media and network theory. It is therefore no coincidence that Michael Rothberg took his leading term 'multidirectional' from network theory.

The notion of multidirectional memory had already been invented avant la lettre by writers of trauma novels before it was theorised in the framework of memory studies. In his novel Slaughterhouse Five (1969), Kurt Vonnegut connected the trauma of the bombings of Dresden with the Vietnam War. His protagonist Billy Pilgrim is the father of Robert Pilgrim, a soldier of the Vietnam War, which was contemporary to Vonnegut's writing his own biographical trauma 23 years after the event. In his novel Extremely Close and Incredibly Loud(2005), Jonathan Safran Foer 
connected the experience of the trauma of 9/11/2001 with the bombings of Dresden on 13 February 1945 and the nuclear bomb dropped on Hiroshima on 6 August 1945. The term 'multidirectional memory' was introduced by Michael Rothberg in an influential study in 2009. In doing so, he addressed a serious issue in current memory practice, which has to do with a tendency inherent in national memories of victimhood to become more and more irreconcilable and non-competitive, thus blocking the path towards shared and transnational memories. His book is designed as a remedy against the trap of competitive victimhood and the conceptual impasse that it has created. The subtitle of his book is: Remembering the Holocaust in the Age of Decolonization. Rothberg focuses on two paradigmatically irreconcilable victimhood memories, namely the Holocaust and the crimes of colonialism, with the aim of showing how they can be productively connected, rather than remaining fixed in a polemic opposition.

The staging of memories in a global arena has also exacerbated the worldwide competition for victimhood and concomitant claims for recognition and resources. Rothberg refers to this logic of mutual exclusion, citing the voice of a black activist: 'the black holocaust was 100 times worse than the so-called Jew Holocaust. You say you lost six million. We [...] lost 600 million'. ${ }^{11}$ Toni Morrison dedicated her novel Beloved (1987), for which she received the Nobel Prize, 'To the sixty million and more'. Oprah Winfrey, who played a leading role in the film that was made of this book, commented on it: 'This is my Schindler's List!" ${ }^{12}$ Rothberg starts from such collisions of memory, introducing his concept of 'multidirectional memory' to subvert this destructive logic. His alternative to mutual repression and denial is a linking of different historical traumas. After the hegemony of holocaust memory has been established in the global world, Rothberg is eager to show that this does not necessarily imply the displacement or erasure of other memories but, on the contrary, can also lead to emphasising and enhancing them. He analyses ways in which the memory of the Holocaust has also provided a new focus, framework and language for other historical traumas. He argues therefore that Holocaust memory can have an enabling rather than crushing effect on other memories when entering into a relationship with it.

Rothberg's methodical innovation consisted of seeing a potential for solidarity where others had seen only clash and conflicts. In Rothberg's view, the metaphor of a 'black holocaust' does not necessarily signal a competition of victimhood, but can also promote mutual recognition between victims. Thus, the exclusive and singular status of the Holocaust surprisingly does not necessarily prevent the possibility of analogies and parallels. Rothberg writes: 'The model of multidirectional memory posits collective memory as partially disengaged from exclusive versions of cultural identity and acknowledges how remembrance both cuts across and binds together diverse spatial, temporal and cultural sites' (Ref. 11, p. 11).

\section{Obstacles on the Path towards Transnational Memories}

Rothberg's model is an important innovation, opening up new theoretical perspectives and practical possibilities. He has recovered many concrete cases from the 
archive in which the destructive competition for victimhood has been overcome. There are, however, many cases in which the path towards transnational memories is still blocked. Our analytical focus, therefore, should not only be on multidirectionality, but also on the counter movements that are currently blocking this process.

In Europe, for instance, there is as yet no end in sight of renewed collisions and contestations along national borders when it comes to interpreting, representing, and commemorating the European past. The long shadow of Europe's violent past is continued in a number of fault lines, subsumed under the heading of Europe's 'memory wars'. European memory is still divided by the traumatic legacy of two core events of the twentieth century: the Holocaust and the Gulag. While the memory of the Nazi genocide has been transformed into a trans-generational and transnational memory, providing the EU with a 'foundation myth' and a moral yardstick for new member states since 2005, the memory of Stalin's terror has a much more contested and fragmented history, fuelling the national narratives of victimhood of post-Soviet states on the one hand and disappearing from Russian and Western political memory altogether. These memories had also been well preserved in a state of latency through longer periods of political repression. From the point of view of Western intellectuals, this rise of the memory of Stalinism fuelled by the liberated countries was observed with considerable anxiety and irritation. There were two barriers against adopting both the Holocaust and the Gulag as transnational European memories. The first was the concern that a transnational memory of Stalin's crimes might pose a threat to the recently recovered, established and expanded Holocaust memory. Such a combination was also considered to be politically incorrect, because it threatened the singularity of the Holocaust in a unifying theory of totalitarianism. ${ }^{13}$

A possibility to overcome this impasse and create a transnational European memory of both historical traumas was offered by historian Bernd Faulenbach, who in a Truth Commission on Germany's second dictatorship came up with the following diplomatic formula.

(1) The memory of Stalinist Terror must not be allowed to relativise the memory of the Holocaust.

(2) The memory of the Holocaust must not be allowed to trivialise the memory of Stalinist Terror. ${ }^{14}$

The word 'trivialise' can stand here for words such as 'ignore', 'neglect' or 'crowd out'. This formula can overcome the criticism that both crimes would be accepted on an equal footing and thus help to remove the remaining obstacles blocking the path to a more integrated European memory. The assessment that Europe's divided memory could be transformed from a rigid, exclusivist 'either-or' memory into a more differentiated and complex 'as well as' memory, is gradually gaining support. This could eventually imply a de-nationalisation and re-Europeanisation of both the memory of the Holocaust and that of the Gulag without thereby losing historical contexts and local specificity. 


\section{Entangled and Dialogic Memories}

There is yet another obstacle on the path from national to transnational memories that has to do with the traumatic European legacy of the Second World War. In the old framework, national memories were mainly constructed around heroic deeds and heroic suffering. National memories are self-serving and therein closely aligned with political myths, which Peter Sloterdijk has appropriately termed modes of 'selfhypnosis'. They are highly selective and composed in such a way that they are identity-enhancing and self-celebrating. With respect to traumatic events, national narratives provide effective protection shields against those events that a nation prefers to forget. When facing negative events in the past, there are only three honourable roles for the national collective to assume: that of the victor who has overcome the evil; that of the resistor who has heroically fought the evil; and that of the victim who has passively suffered the evil. Everything else lies outside the scope of these memory perspectives and is conveniently forgotten.

Two countries engage in a dialogic memory if they face a shared history of mutual violence by mutually acknowledging their own guilt, which they have inflicted on others, together with their regret and empathy for the other's suffering. It is true that what I call 'dialogic memory' is not yet backed up by a consolidated consensus, but it is still most conspicuous by its absence. It has, for instance, become especially manifest in the relations between Russia and Eastern European nations. While Russian memory is today centred on the great patriotic war and Stalin is celebrated as the national hero, the nations that broke away from Soviet power maintain a strikingly different memory of Stalin that has to do with deportations, forced labour and mass-killings. The triumphalist memory of Russia on the one hand and the traumatic memory of Eastern European nations on the other clash at the internal borders of Europe and fuel continuous irritations and conflicts. 'With respect to its memories', said Janusz Reiter, ${ }^{17}$ previous Polish ambassador to Germany: 'the European Union remains a split continent. After its extension, the line that separated the EU from other countries now runs right through it'. As we all know, the European Union is itself the consequence of a traumatic legacy of an entangled history of unprecedented violence. If it is to develop further from an economic and political network to a community of shared values, the entangled histories will have to be transformed into sharable memories for which the European Union provides an ideal framework for mutual observations, interactions and thus for dialogic remembering.

Within the new memory frame, there are promising beginnings between teachers and historians of neighbouring countries working on shared textbooks and mutual perceptions. Dialogic memory has a special relevance for Europe; it could produce a new type of nation-state that is not exclusively grounded in pride, but is transnationally sensitive to its neighbours, accepting the dark legacies of an entangled history of violence by including the victims of this own violence into its national memory. Such a sensitive transnational memory could credibly back up the protection of human rights in the present and support the values of a civil society in the future. 


\section{Memory Transfers: Elective Affinities, Mirrors, Models}

Most of the memories discussed here are critically related to crimes against humanity with trans-generational long-term effects. While the perpetrators seek to forget and if they are in power - cover up the past with laws of amnesty, thus annulling their own crimes, other countries might step in to take over the perspective of the victims, articulating their claims of the perpetrators' culpability. The new law of 'universal jurisdiction' that was developed in the 1990s took from the nation state the sole responsibility for criminal prosecution and extended it to other states as well. According to a new culture of human rights and ethical responsibility, it was agreed 'that states have a logical and moral duty to prosecute an individual' responsible for crimes that pose a threat to the international community. It was further specified that 'no place should be a safe haven' for those who have committed the following crimes:

- genocide

- crimes against humanity

- extrajudicial executions

- war crimes

- torture

- forced disappearances. ${ }^{15}$

The International Criminal Court (ICC) was established in The Hague in 2003 to take over such international responsibility, but it is confined to crimes committed after 2002. Within this new global system of vigilance, various high military leaders of the Chilean and Argentinian dictatorship, starting with Pinochet, were prosecuted in Spain for crimes in trials from which they were protected in their home countries. In reaction to this external international pressure, Argentina annulled its amnesty laws in 2003. Since then, we have been witnessing in the Western world the emergence of new transnational standards of human rights policy and universal jurisdiction.

A fascinating case of a transnational memory-alliance has developed over the years between Spain and Argentina. When, due to its amnesty laws, Argentina was unwilling to face the criminal past of the dictatorship and investigate the cases of forced disappearances, Spain stepped in and took over the question of legal accountability in the name of the victims between 1999 and 2007 in the national Spanish court. When, however, star jurist Baltasar Garzón attempted to bring Spanish crimes to trial and filed charges against Francoist atrocities, he was immediately suspended from office (2010). In this situation, defined by Spanish laws guaranteeing impunity and immunity, it was then the Argentinian court that took over, dealing with the cases of Republicans who 'disappeared' during and after the Spanish Civil War and are still hidden in mass graves.

There are close links between transnational legal developments and social memory practices of civil rights groups. In her study of this new international alliance relating to the respective traumatic legacies in Spain and Argentina, Ulrike Capdepón has duly emphasised a striking conceptual memory transfer from Argentina to Spain. ${ }^{16}$ This concerns the term 'desaparecido' (disappeared), which was developed and gained visibility in the civil movement of the 'Madres de Plaza de Mayo'. Elaborated in a long period of civil rights activism, this term has, in the meantime, gained global 
visibility and juridical valance. It can be described as a 'memory icon' that arouses attention, creates visibility, stirs debates and supports claims. Imported into the Spanish debate, the term replaced the euphemistic language of the perpetrators who had spoken of the disappeared as 'paseados' (walkers), challenging the national narrative about those Republicans who had disappeared during and after the Civil War. It is estimated that up to 150,000 Republicans disappeared in clandestine mass graves, from which they have been exhumed since 2000 by the third generation. The introduction of the Argentinian terminology and symbols served as an external trigger for Spanish memories to re-emerge in the social debates.

Capdepón describes in detail how one civil society can learn from another by such a transfer of concepts, forms of protest and memorial practices between different nations. She sums up: 'The public forms of dealing with a historic legacy of extreme violence and crimes against humanity have moved progressively into a global context and have created new forms of transatlantic entanglements, influences and alliances' ${ }^{16}$ It is interesting to note that, in this case, the normative impulse does not follow the colonial trajectory from Europe to the southern hemisphere, but issues in reverse from a former colony and is directed towards Europe. This movement has been referred to as a 'boomerang effect'. I do not quite like this metaphor that implies a threatening aggression returning to its point of origin. I would rather speak here of an extension of the 'politics of regret', which also has a strong basis in Europe.

Transnational history, as Micol Seigel rightly emphasised, 'treats the nation as one among a range of social phenomena to be studied, rather than the frame of the study itself'. It has replaced the frame of the nation by the frame of the transnational, thus challenging bounded views on national belonging and opening up new perspectives for the internal differences and relational connectedness of nations. My brief sketch of seven types of transnational memories can in no way do justice to the complexity of the topic, let alone aim at presenting an inclusive picture of even the most important transnational memory sites. (One important, unique and highly influential type is missing, for instance: the UNESCO world heritage project which goes back to the convention of 1972 , signed by its member states for the protection of the world cultural and natural heritage.) It is hoped, however, that this paper may stimulate reflection and research by producing new evidence, further differentiation, and a more detailed assessment and evaluation of the new and challenging field of transnational memories.

\section{References and Notes}

1. M. Seigel (2005) Beyond compare. Comparative method after the transnational turn. Radical History Review, 91, p. 63.

2. D. E. Pease (2011) Introduction: re-mapping the transnational turn. In: W. Fluck, D. E. Pease and J. C. Rowe (eds), Re-Framing the Transnational Turn in American Studies (Hanover, New Hampshire: Dartmouth College Press), p. 5.

3. A. Assmann and S. Conrad (eds) (2010) Memory in a Global Age: Discourses, Practices and Trajectories (Basingstoke: Palgrave Macmillan), p. 2.

4. D. Levy and N. Sznaider (2006) The Holocaust in the Global Age (Philadelphia, PA: Temple University Press). 
5. A. Rigney (2012) Transforming memory and the European project. New Literary History, 43(4), p. 618.

6. In 2012, the ITF was renamed as the 'International Holocaust Remembrance Alliance' (IHRA) and changed its logo, thus abandoning possible military or colonial associations lingering in the terminology. The new logo of the IHRA is a global emblem designed by Daniel Libeskind.

7. J. Kroh (2008) Transnationale Erinnerung. Der Holocaust im Fokus geschichtspolitischer Initiativen (Frankfurt am Main: Campus Verlag), p. 107.

8. C. Meier (2001) Das Verschwinden der Gegenwart. Über Geschichte und Politik (München: Hanser), p. 24. (my translation).

9. For a more detailed view of this transnational memory in the making, see W. Kaiser, S. Krankenhagen and K. Poehls (2012) Europa ausstellen. Das Museum als Praxisfeld der Europäisierung (Köln: Böhlau Verlag), lines 408, 417 and 446.

10. M. Foucault (1971) The Archaeology of Knowledge and the Discourse on Language (trans. A. M. Sheridan Smith) (New York: Pantheon Books), p. 23.

11. M. Rothberg (2009) Multidirectional Memory. Remembering the Holocaust in the Age of Decolonization (Stanford: Stanford University Press), p. 1.

12. D. Chakrarbarty (2007) History and the politics of recognition. In: K. Jenkins, S. Morgan and A. Munslow (eds), Manifestos for History (London and New York: Routledge), p. 82.

13. Dan Diner, for instance, has opposed such a comparison most emphatically and disqualified any such attempt as a priori ideologically warped. He suspects that such a comparison is not immune to the hidden agenda of proving that 'Stalin's crimes are more reprehensible than those of the Nazis'. D. Diner (1995) Kreisläufe. Nationalsozialismus und Gedächtnis (Berlin: Berlin Verlag), p. 53. See also Heidemarie Uhl, who still sees these two memories as incompatible: H. Uhl (2009) Konkurrierende Erinnerungskulturen in Europa: Neue Grenzen zwischen 'Ost' und 'West'?. In: H. Fassmann, W. Müller-Funk and H. Uhl (eds), Kulturen der Differenz - Transformationsprozesse in Zentraleuropa nach 1989. Transdisziplinäre Perspektiven (Göttingen: Vienna University Press), pp. 165-177; S. Troebst (2005) Jalta versus Stalingrad, GULag versus Holocaust. Konfligierende Erinnerungskulturen im größeren Europa. Berliner Journal für Soziologie, 15(3), pp. 381-400.

14. B. Faulenbach (1993) Probleme des Umgangs mit der Vergangenheit im vereinten Deutschland. Zur Gegenwartsbedeutung der jüngsten Geschichte. In: W. Weidenfeld (ed.), Deutschland. Eine Nation - doppelte Geschichte. Materialien zum deutschen Selbstverständnis (Cologne: Verlag Wissenschaft und Politik), p. 190.

15. http://en.wikipedia.org/wiki/Universal_jurisdiction

16. U. Capdepón Busies (2013) Universelle Gerichtsbarkeit zur Auseinandersetzung mit Diktatur und Staatsterror: Transnationale Narrative des Verschwindenlassens zwischen Argentinien und Spanien. Paper given at the University of Konstanz on 10 May 2013.

17. Janusz Reiter, 'Geteilte Erinnerung in vereinten Europa,' Frankfurter Allgemeine Zeitung, 7 May 2005.

\section{About the Author}

Aleida Assmann is Professor of English Literature and Literary Theory at the University of Konstanz, Germany. She received an Honorary Degree from the University of Oslo (2008) and the Max Planck Research Award (2009). Her main areas of research are historical anthropology, history of media, history and theory of reading and writing, and cultural memory, with special emphasis on Holocaust and trauma. 